\title{
Effect of Fermentation on Physicochemical Properties and Oxalate Content of Cocoyam (Colocasia esculenta) Flour
}

\author{
M. O. Oke ${ }^{1}$ and I. F. Bolarinwa ${ }^{2}$ \\ ${ }^{1}$ Department of Food Science and Engineering, Ladoke Akintola University of Technology, PMB. 4000, Ogbomoso, Oyo state, Nigeria \\ 2 Procter Department of Food Science, University of Leeds, Leeds LS2 9JT, UK
}

Correspondence should be addressed to M. O. Oke, ola4ade@yahoo.com

Received 8 August 2011; Accepted 10 September 2011

Academic Editors: A. Berville and N. Maruyama

Copyright (C) 2012 M. O. Oke and I. F. Bolarinwa. This is an open access article distributed under the Creative Commons Attribution License, which permits unrestricted use, distribution, and reproduction in any medium, provided the original work is properly cited.

\begin{abstract}
The effect of fermentation on physicochemical properties and oxalate content of cocoyam (Colocasia esculenta) flour was evaluated. The cocoyam, white flesh was cleaned, washed, peeled, sliced into chips of $2-2.5 \mathrm{~cm}$ thickness, soaked in tap water and left to ferment for $24 \mathrm{~h}$ and $48 \mathrm{~h}$. The fermented cocoyam was then drained, dried in cabinet dryer at $60^{\circ} \mathrm{C}$ for $24 \mathrm{~h}$ and milled. The flour samples were passed through a $45 \mu \mathrm{m}$ mesh size sieve. Unfermented cocoyam flour was also produced and served as a control. Calcium oxalate and some physicochemical properties of flours from the fermented cocoyam were compared with the unfermented flour. Results showed that fermentation effected a significant reduction in oxalate level (58 to 65\%) depending on the fermentation period. The amylose content was higher in $48 \mathrm{~h}$ fermented flour $(55.52 \%)$ than in $24 \mathrm{~h}(54.55 \%)$. Pasting (gelatinization) temperature decreased, and water absorption capacity increased markedly due to fermentation.
\end{abstract}

\section{Introduction}

Cocoyams are the third most important root crop (after yam and cassava) cultivated in West Africa. More than three quarters of the world cocoyam production come from Africa with Ghana and Nigeria being the world's leading producers [1]. They are also important crops in Hawaii, Japan, and Egypt [2]. In general, they are stem tubers that are widely cultivated in both the tropical and subtropical regions of regions of the world [3]. Among seven species of Colocasia (taro) which originated from Asia and about forty species of Xanthosoma (tannia) from America, the two species mostly grown in West Africa are Colocasia esculenta and Xanthosoma sagittifolium $[3,4]$.

The Xanthosoma sagittifolium variety in Nigeria is hard and highly starchy which makes it easy for fufu preparation while Colocasia esculenta, with a softer tuber is usually prepared and eaten like yam. It produces a more floury starch suitable for use in composite mixture for food preparations. In some Nigerian diets, the cormels and young leaves of the taro variety serve as leafy vegetables [5]. Cocoyams can also be processed in several ways to produce food and feed products similar to that of potatoes in the Western world. Among the processes cocoyam can be subjected to, are boiling, roasting, frying, milling, and conversion to "fufu", soup thickeners, flour for baking, chips, beverage powder, porridge, and speciality food for gastrointestinal disorders [5-8].

Several studies have shown that cocoyams contain digestible starch, protein of good quality, vitamin C, thiamin, riboflavin, niacin, and high scores of amino acids [9]. However, one major limiting factor in the utilization of cocoyam is the presence of oxalates, which impart acrid taste or cause irritation when foods prepared from them are eaten. Ingestion of foods containing oxalates has also been reported to cause caustic effects, irritation to the intestinal tract and absorptive poisoning. Oxalates are also known to interfere with the bioavailability of calcium [10].

Cocoyam has been processed in many ways to reduce its oxalate content and produce good-quality flour; however, application of flour from different plant or animal sources in food systems depends greatly on information about the physicochemical properties of such food materials [11]. The 
levels of oxalate in locally grown cocoyams are important in the assessment of their nutritional status. Hence, the objectives of this research were to determine the effect of fermentation on functional, pasting properties, and oxalate content of cocoyam flour.

\section{Materials and Methods}

2.1. Sample Preparation. Cocoyams (Colocasia esculenta) were purchased from a local market in Ogbomoso, Oyo state, Nigeria. The cocoyams were cleaned, washed, peeled, sliced into chips of $2-2.5 \mathrm{~cm}$ thickness, soaked in tap water, and left to ferment for $24 \mathrm{~h}$, and $48 \mathrm{~h}$. The fermented cocoyams were drained, dried in cabinet dryer at $60^{\circ} \mathrm{C}$ for $24 \mathrm{~h}$ and milled. The flour samples were then passed through a $45 \mu \mathrm{m}$ mesh size sieve. Unfermented cocoyam flour was also produced.

2.2. Pasting Properties Studies. The pasting profiles of the flour samples were studied using a Rapid Visco-Analyzer (RVA) (Newport Scientific Pty. Ltd.) with the aid of a thermocline for windows version 1.1 software (1996) as described by Adeyemi et al. [12]. The following parameters were obtained from the pasting profile: peak viscosity, pasting temperature, setback viscosity, breakdown viscosity, final viscosity, and time to reach the peak viscosity.

2.3. Determination of Functional Properties. The swelling power and solubility index were determined by the methods of Konik et al. [13] and Gudmundsson and Alliasson [14], in a thermostatic Clifton water bath over a temperatures range of $50-95^{\circ} \mathrm{C}$. Amylose content of the cocoyam flours were determined by iodine potentiometric titration (IPT). Before evaluation of iodine affinity, the starch was thoroughly defatted for $48 \mathrm{~h}$ with $85 \%$ methanol by Soxhlet extraction and the samples were dried and pulverized to pass through a $45 \mu \mathrm{m}$ mesh size sieve $[15,16]$. Water absorption capacity (WAC) was determined using the method of Mbofung et al. [17].

2.4. Oxalate Determination. The oxalate content of the cocoyam flours were determined by titrating an aliquot of extracts from the homogenized samples with $0.01 \mathrm{M}$ $\mathrm{KMnO}_{4}$ solution [18]. Prior to determination, the heavy metals in the acidified extracts were precipitated with $5 \mathrm{~mL}$ tungstosphophoric acid reagent and centrifuged at $1700 \mathrm{rpm}$ for $15 \mathrm{~min}$, as described by Sefa-Dedeh and Agyir-Sackey [10].

2.5. Statistical Analysis. The data obtained from the studies were analyzed using one factor analysis of variance (ANOVA) and Turkey mean separation for multiple comparisons with the Statistical Analysis System (SAS) program [19]. Significance was accepted at $P \leq 0.05$.

\section{Results and Discussion}

3.1. Pasting Properties. The effect of fermentation on the pasting properties of cocoyam flour is presented in Table 1.
TABLE 1: Pasting properties of fermented cocoyam flours obtained from RVA Viscoamylograph.

\begin{tabular}{lccc}
\hline Attributes & $\begin{array}{c}\text { Control } \\
\text { 0h fermentation }\end{array}$ & $\begin{array}{c}24 \text { hours } \\
\text { fermentation }\end{array}$ & $\begin{array}{c}48 \text { hours } \\
\text { fermentation }\end{array}$ \\
\hline $\begin{array}{l}\text { Pasting } \\
\text { temperature }\left({ }^{\circ} C\right)\end{array}$ & $64.08 \pm 0.7^{\mathrm{a}}$ & $63.58 \pm 0.5^{\mathrm{a}}$ & $63.30 \pm 0.5^{\mathrm{a}}$ \\
\hline $\begin{array}{l}\text { Peak viscosity } \\
(\mathrm{RVU})\end{array}$ & $178.75 \pm 10.8^{\mathrm{a}}$ & $133.08 \pm 5.4^{\mathrm{b}}$ & $124.46 \pm 6^{\mathrm{b}}$ \\
\hline $\begin{array}{l}\text { Trough }(\mathrm{RVU}) \\
\text { Breakdown }(\mathrm{RVU})\end{array}$ & $\begin{array}{r}62.84 \pm 5.1^{\mathrm{a}} \\
\hline \begin{array}{l}\text { Final viscosity } \\
\text { (RVU) }\end{array}\end{array}$ & $58.83 \pm 1.9^{\mathrm{b}}$ & $66.96 \pm 5.3^{\mathrm{a}}$ \\
\hline Setback (RVU) & $51.54 \pm 2.4^{\mathrm{a}}$ & $53.00 \pm 4.0^{\mathrm{a}}$ & $42.08 \pm 1.1^{\mathrm{b}}$ \\
\hline Peak time (min.) & $5.68 \pm 0.1^{\mathrm{a}}$ & $5.56 \pm 0.1^{\mathrm{a}}$ & $4.46 \pm 0.2^{\mathrm{b}}$ \\
\hline
\end{tabular}

Means followed by different superscript within the same row are significantly different $(P \leq 0.05)$.

The pasting temperature of the $24 \mathrm{~h}$ and $48 \mathrm{~h}$ fermented cocoyam flours were 63.58 and $63.30^{\circ} \mathrm{C}$, respectively. The pasting temperatures of the fermented flours were not significantly different from the unfermented flour $\left(64.08^{\circ} \mathrm{C}\right)$. Nwokocha et al. [20] reported that lower pasting temperature $\left(68^{\circ} \mathrm{C}\right)$ and rapid rise in viscosity to peak $(845 \mathrm{BU}$ at $\left.78^{\circ} \mathrm{C}\right)$ of cassava starch relative to cocoyam starch $\left(78^{\circ} \mathrm{C}\right.$, pasting temperature and peak viscosity, $630 \mathrm{BU}$ at $91^{\circ} \mathrm{C}$ ) indicate a weak granular structure of cassava compared to cocoyam.

The peak viscosity of $24 \mathrm{~h}$ and $48 \mathrm{~h}$ fermented cocoyam flour was 133.08 and 124.46 RVU, respectively. Flour with a lower peak viscosity has a lower thickening power than flour with a higher peak viscosity; therefore, $48 \mathrm{~h}$ fermented cocoyam flour has a lower thickening power than $24 \mathrm{~h}$ fermented cocoyam flour. The final viscosity of the $24 \mathrm{~h}$ and $48 \mathrm{~h}$ fermented flour (159.25 and 157.58 RVU) was not significantly different from the unfermented flour (167.46). The final viscosity of cocoyam starch paste is related to the amylose content. Flour with higher amylose content gives a higher final viscosity.

The setback from trough is also related to the amylose content and reflects retrogradation of starch. The setback values of the flours were 53 and 42.08 RVU for $24 \mathrm{~h}$ and $48 \mathrm{~h}$ fermented flours, respectively. There were no significant differences $(P \leq 0.05)$ in the setback values of the fermented and the unfermented flour (51.54 RVU). The setback values obtained in this study indicates a higher retrogradation tendency of cocoyam flour. This property of cocoyam starch makes it suitable for use in jelly foods. Earlier work also reported a higher setback ratio for cocoyam starch paste (2.50) when compared with (2.0) cassava starch paste [20].

Trough value ranged from 104.25 to 117.50 RVU for $24 \mathrm{~h}$ and $48 \mathrm{~h}$ fermented flour, respectively. Flour from $48 \mathrm{~h}$ fermentation had higher trough than flour from $24 \mathrm{~h}$ fermentation. Trough increased with increase in fermentation period. However, there were no significant differences $(P \leq 0.05)$ in trough among fermented flour samples and the unfermented flour. Trough value is the maximum viscosity value in the 
TABLE 2: Functional properties of fermented cocoyam flour.

\begin{tabular}{lccc}
\hline \% composition & $\begin{array}{c}\text { Control } \\
\text { 0 fermentation }\end{array}$ & $\begin{array}{c}24 \text { hours } \\
\text { fermentation }\end{array}$ & $\begin{array}{c}48 \text { hours } \\
\text { fermentation }\end{array}$ \\
\hline Sugar & $2.40 \pm 0.1^{\mathrm{a}}$ & $2.11 \pm 0.1^{\mathrm{a}}$ & $1.74 \pm 0.1^{\mathrm{b}}$ \\
Starch & $55.08 \pm 1.5^{\mathrm{a}}$ & $54.55 \pm 0.1^{\mathrm{a}}$ & $55.26 \pm 0.5^{\mathrm{a}}$ \\
Amylose & $14.79 \pm 0.0^{\mathrm{b}}$ & $15.44 \pm 0.1^{\mathrm{a}}$ & $15.52 \pm 00^{\mathrm{a}}$ \\
Amylopectin & $97.59 \pm 0.1^{\mathrm{b}}$ & $97.89 \pm 0.1^{\mathrm{b}}$ & $98.26 \pm 0.1^{\mathrm{a}}$ \\
Water & & & \\
absorption & $231.29 \pm 1.4^{\mathrm{b}}$ & $271.11 \pm 1.0^{\mathrm{a}}$ & $287.59 \pm 2.1^{\mathrm{a}}$ \\
capacity & & & \\
Swelling power & $17.50 \pm 0.6^{\mathrm{a}}$ & $18.31 \pm 0.0^{\mathrm{a}}$ & $18.45 \pm 0.0^{\mathrm{a}}$ \\
Solubility index & $16.21 \pm 0.4^{\mathrm{b}}$ & $17.33 \pm 0.2^{\mathrm{a}}$ & $18.53 \pm 0.3^{\mathrm{a}}$ \\
\hline
\end{tabular}

Means followed by different superscript within the same row are significantly different $(P \leq 0.05)$

constant temperature phase of the RVA profile and measures the ability to withstand breakdown during cooling [11].

Breakdown value was between 58.83 and $66.96 \mathrm{RVU}$. The $48 \mathrm{~h}$ fermented flour had the highest breakdown value (66.96 RVU) while the $24 \mathrm{~h}$ fermented flour had the lowest value (58.83 RVU). Breakdown increased with increase in fermentation period of the flour samples. The breakdown value reported in this study was, however, different from the results of a study on the properties of starches from cocoyam (Xanthosoma sagittifolium) tubers planted from different seasons, which reported the breakdown values of 126-186 and $232-840 \mathrm{cP}$ for cocoyam starches [15]. The discrepancy indicated that breakdown value of cocoyam flour and starch varied with plant species. Breakdown viscosity value is a measure of the ease with which the swollen granules can be disintegrated [21] and, hence, an index of the stability of starch [22].

Peak time of the $24 \mathrm{~h}$ and $48 \mathrm{~h}$ fermented flour was 5.56 and $4.46 \mathrm{~min}$, respectively. Peak time decreased with increase in fermentation period. There were significant differences $(P \geq 0.05)$ in the peak time of the two flour samples. Peak time is an indication of the minimum temperature required to cook flour [11]. The peak time reported in this study is close to that of instant yam-bread fruit (5.13 to $5.80 \mathrm{~min}$ ) composite flour [23].

3.2. Functional Properties. The functional properties of the fermented cocoyam flours are presented in Table 2. The sugar content ranged from 1.74 to $2.40 \%$, with the unfermented flour having the highest value while the $48 \mathrm{~h}$ fermented flour had the least value. The sugar content of the flour decreased with increase in fermentation period. This indicates that, the longer the fermentation period, the higher the microbial population and, hence, the higher the consumption of soluble sugars. This is in agreement with earlier studies [2426].

Total starch contents of fermented cocoyam flours ranged from 54.55 to $55.26 \%$ for $24 \mathrm{~h}$ and $48 \mathrm{~h}$ fermented flour, respectively. There were no significant differences $(P \leq 0.05)$ between the starch content of fermented and unfermented flours. Total starch content obtained in this study was close
TABLe 3: Calcium oxalate content of fermented cocoyam flour.

\begin{tabular}{lc}
\hline Sample & Oxalate content $(\%)$ \\
\hline 0 h fermented & $5.71 \pm 0.0^{\mathrm{a}}$ \\
24 h fermentation & $2.38 \pm 0.0^{\mathrm{b}}$ \\
$48 \mathrm{~h}$ fermentation & $1.99 \pm 0.0^{\mathrm{c}}$ \\
\hline
\end{tabular}

Means followed by different superscript within a column are significantly different $(P \leq 0.05)$.

to the range (81.1-87.7\%) reported by $\mathrm{Lu}$ et al. [15] for cocoyam (Xanthosoma sagittifolium) starches.

The amylose and amylopectin content of the $24 \mathrm{~h}$ and $48 \mathrm{~h}$ fermented flour were (15.44 and 15.52\%) and (97.89 and $98.26 \%$ ), respectively. The amylose content of the fermented flours was higher than the unfermented flour $(14.79 \%)$. This observation could be explained by the likely formation of amylose-like materials resulting from enzyme/acid hydrolysis of amylopectin at the amorphous regions of the starch granule during fermentation [26]. The amylose content of the fermented cocoyam flour in this study, was close to the amylose content of fermented cassava starches (18.23-20.35\%) reported by Numfor [26]. The percentage of amylopectin in cocoyam flour in this study was higher than the range reported by $\mathrm{Lu}$ et al. [15] for cocoyam (Xanthosoma sagittifolium) starches (2.47-2.89\%). This may be as a result of the different species of cocoyam used for the studies.

The water absorption capacity of the flour increased from 231.29 to $287.59 \%$ with the unfermented flour having the lowest value. The water absorption capacity increased with increasing fermentation period. The result of this study agreed with the water absorption capacity of cocoyam flour (296-344\%) produced from boiled cocoyam at different time interval [2].

The swelling power and solubility index of the fermented flour range from 18.31 to $18.45 \%$ and 17.33 to $18.53 \%$, respectively. Differences in swelling and solubility are indication of difference in the bonding forces within the starch granules. During increased thermal agitation, the bond relax, thereby causing starch granules to imbibe water in swell and a low molecular weight amylase solubilize and leach out into the aqueous medium [27]. The swelling and solubility index of the fermented flours were not significantly different $(P \leq 0.05)$. The swelling and solubility profiles indicate that cocoyam flour had greater intragranular organization in which most of the bonding forces required energy supplied in the temperature range of $75-80^{\circ} \mathrm{C}$ to cause relaxation [20].

3.3. Calcium Oxalate Content. The results (Table 3) show that the oxalate content of the flour decreased from $5.71 \%$ (unfermented flour) to $1.99 \%$ ( $48 \mathrm{~h}$ fermented flour). Oxalate content decreased with increase in fermentation period. There was a $65 \%$ reduction in oxalate content of the $48 \mathrm{~h}$ fermented flour when compared with the unfermented flour. The oxalate content of the $24 \mathrm{~h}$ fermented flour was also reduced by $58 \%$. The observed marked reduction caused by fermentation may be due to the effect of leaching and enzyme/acid hydrolysis of the starch granule during 
fermentation. Iwuoha and Kalu [2] also reported $82.1 \%$ and $61.9 \%$ oxalate reduction in cocoyam flour produced from boiled and roasted cocoyam, respectively.

\section{Conclusion and Recommendation}

Fermentation affected the calcium oxalate and some physicochemical properties of cocoyam flour. Calcium oxalate was reduced significantly; the greatest reduction was observed in the $48 \mathrm{~h}$ fermentation, which reduced the oxalate level by approximately $65 \%$. Water absorption capacity of the fermented cocoyam increased markedly, and viscosity was reduced. The high setback value of fermented cocoyam flour makes it suitable for jelly foods. Further work needs to be carried out on the effect of longer fermentation period (72-96 h), as well as the microorganism associated with the fermentation, and, if possible, the development of starter culture to ferment cocoyam, to see changes on the oxalate content and other physicochemical properties of cocoyam flour.

\section{References}

[1] I. C. Onwueme, The Tropical Tuber Crops. English Language Book Society, John Wiley \& Sons, Chichester, UK, 1982.

[2] C. I. Iwuoha and F. A. Kalu, "Calcium oxalate and physicchemical properties of cocoyam (Colocasia esculenta and Xanthosoma sagittifolium) tuber flours as affected by processing," Food Chemistry, vol. 54, pp. 61-66, 1995.

[3] J. W. Purseglove, "Araceae," in Tropical Crops: Monocotyledons, pp. 58-74, Longman, Essex, UK, 1972.

[4] F. R. Irvine, "Cocoyam," in West African Crops, pp. 174-179, Oxford University Press, Oxford, UK, 1969.

[5] A. I. Ihekoronye and P. O. Ngoddy, "Cocoyams," in In Integrated Food Science and Technology for the Tropics, pp. 280281, Macmillan, London, UK, 1985.

[6] C. I. Onwueme, "Colocosia and xanthosoma," in The Tropical Tuber Crops, pp. 199-227, John Wiley \& Sons, New York, NY, USA, 1978.

[7] M. Hussain, G. Norton, and R. J. Neale, "Composition and nutritive value of cornmeal of Colocasia esculenta (L) Schott," Journal of the Science of Food and Agriculture, vol. 35, pp. 11121119, 1984.

[8] O. C. Obiechina and A. A. Ajala, "Socioeconomic and cultural importance of cocoyam as a Staple food," in Proceedings of the 1st National Workshop on Cocoyam (NRCRI '87), pp. 180-184, Umudike, Nigeria, 1987.

[9] O. Onayemi and N. C. Nwigwe, "Effect of processing on the oxalate content of cocoyam," Food Science and Technology, vol. 20, no. 6, pp. 293-295, 1987.

[10] S. Sefa-Dedeh and E. K. Agyir-Sackey, "Chemical composition and the effect of processing on oxalate content of cocoyam Xanthosoma sagittifolium and Colocasia esculenta cormels," Food Chemistry, vol. 85, no. 4, pp. 479-487, 2004.

[11] C. E. Chinma, O. Adewuyi, and J. O. Abu, "Effect of germination on the chemical, functional and pasting properties of flour from brown and yellow varieties of tigernut (Cyperus esculentus)," Food Research International, vol. 42, no. 8, pp. 1004-1009, 2009.

[12] I. A. Adeyemi, B. O. Adabiri, O. A. Afolabi, and O. L. Oke, "Evaluation of some quality characteristics and baking poten- tials of amaranth flour," Nigerian Food Journal, vol. 10, pp. 815, 1992.

[13] C. M. Konik, D. M. Kiskelly, and P. W. Gras, "Starch: swelling power, grain hardness and Protein. Relation to sensory properties of Japanese noodles," Starch/Störke, vol. 45, no. 4, pp. 139-144, 1993.

[14] M. Gudmundsson and A. C. Alliasson, "Gel volume and amylase leaching," Journal of Cereal Science, vol. 68, no. 2, pp. 172-177, 1991.

[15] T. J. Lu, J. C. Chen, C. L. Lin, and Y. H. Chang, "Properties of starches from cocoyam (Xanthosoma sagittifolium) tubers planted in different seasons," Food Chemistry, vol. 91, no. 1, pp. 69-77, 2005.

[16] T. J. Schoch, "Iodometric determination of amylase," in Methods in Carbohydrate Chemistry, R. L. Whistler, R. L. Smith, J. N. BeMiller, and M. L. Wolfrom, Eds., vol. 4, pp. 157160, Academic Press, New York, NY, USA, 1964.

[17] C. M. F. Mbofung, Y. N. Abubakar, A. Njintang, B. Abduo, and F. Balaam, "Physico-chemical and functional properties of six varieties of Taro (Colocasia esculenta L. schott) flour," Journal of Food Technology, vol. 4, no. 2, pp. 135-142, 2006.

[18] AOAC, Official Methods of Analysis, vol. 2, Association of Official Analytical Chemistry, Washington, DC, USA, 15th edition, 1990.

[19] SAS Institute Inc., SAS ${ }^{\circledR} 9.1$ Qualification Tools User's Guide, SAS Institute Inc., Cary, NC, USA, 2003.

[20] L. M. Nwokocha, N. A. Aviara, C. Senan, and P. A. Williams, "A comparative study of some properties of cassava (Manihot esculenta, Crantz) and cocoyam (Colocasia esculenta, Linn) starches," Carbohydrate Polymers, vol. 76, no. 3, pp. 362-367, 2009.

[21] M. Kaur and N. Singh, "Studies on functional, thermal and pasting properties of flours from different chickpea (Cicer arietinum L.) cultivars," Food Chemistry, vol. 91, no. 3, pp. 403-411, 2005.

[22] M. L. Fernanadaz de Tonella and J. W. Berry, "Rheological properties of flour and sensory characteristics of bread made from germinated chickpeas," International Journal of Food Science \& Technology, vol. 10, pp. 121-129, 1989.

[23] A. A. Adebowale, S. A. Sanni, and F. O. Oladapo, "Chemical, functional and sensory properties of instant yam-bread fruit flour," Nigerian Food Journal, vol. 26, no. 1, pp. 2-12, 2008.

[24] O. G. Longe, "Effect of processing on the chemical composition and energy value of cassava," Nutrition Reports International, vol. 21, no. 6, pp. 819-828, 1980.

[25] D. O. Ezeala, "Changes in the nutritional quality of fermented cassava tuber meal," Journal of Agricultural and Food Chemistry, vol. 32, no. 3, pp. 467-469, 1984.

[26] F. A. Numfor, "Physicochemical changes in cassava starch and flour associated with fermentation, effect on textural properties," Journal of Food Technology in Africa, vol. 4, no. 1, pp. 31-35, 1999.

[27] C. Balagopalan, G. Padmaja, S. K. Nanda, and S. N. Moorthy, Cassava in Food, Feed and Industry, CRC Press, Boca Raton, Fla, USA, 1988. 


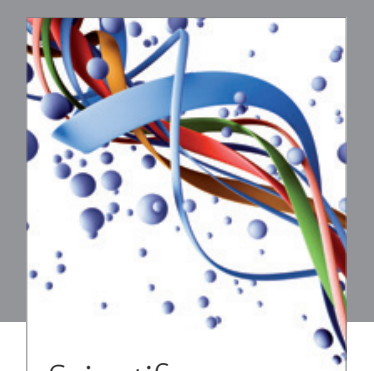

Scientifica
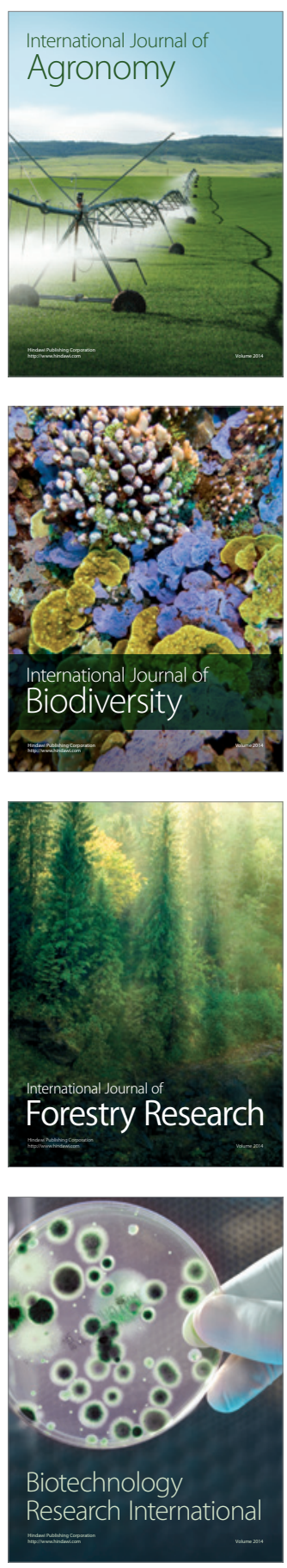
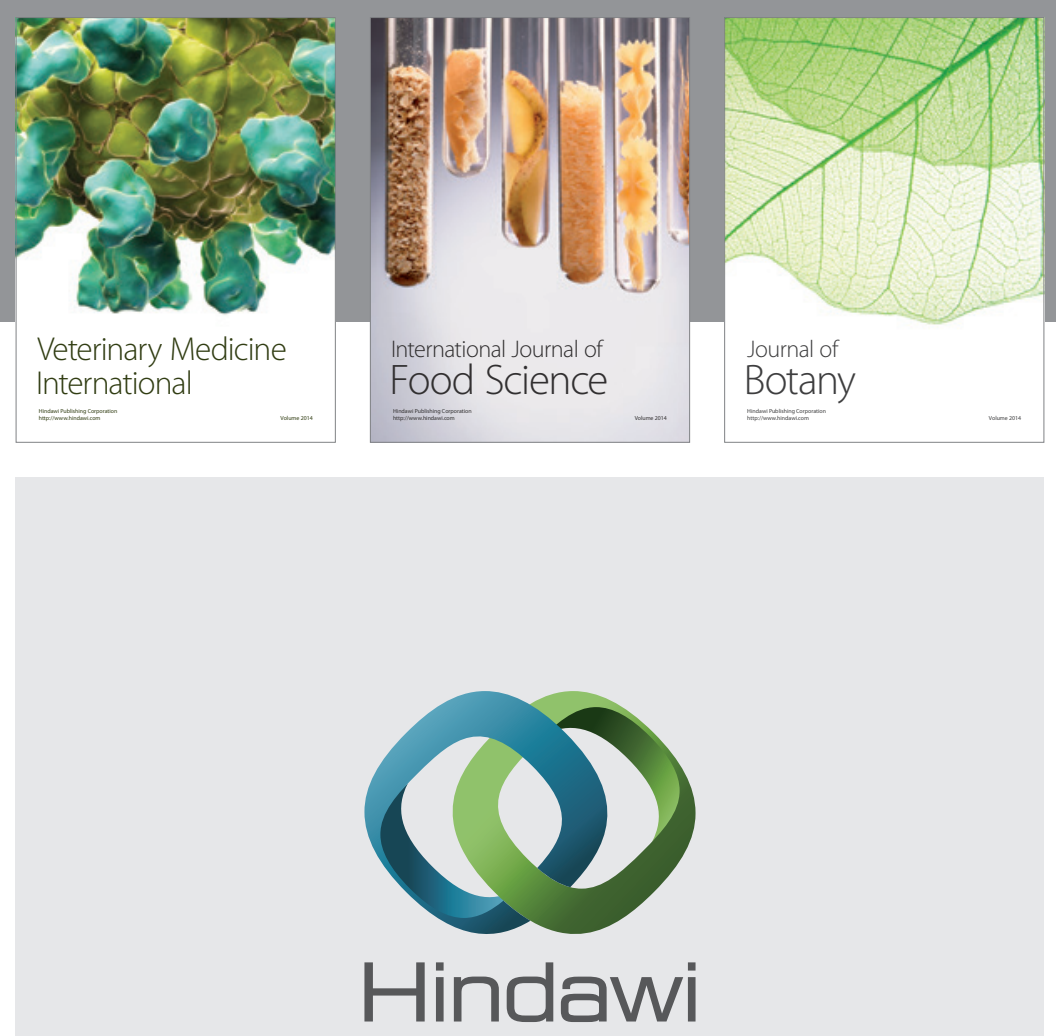

Submit your manuscripts at

http://www.hindawi.com
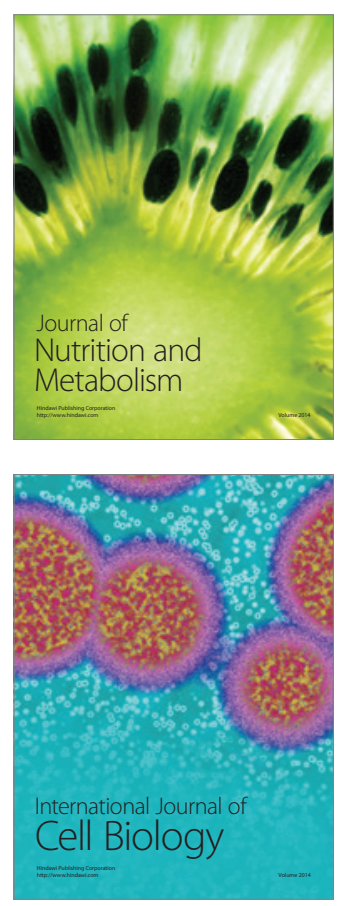
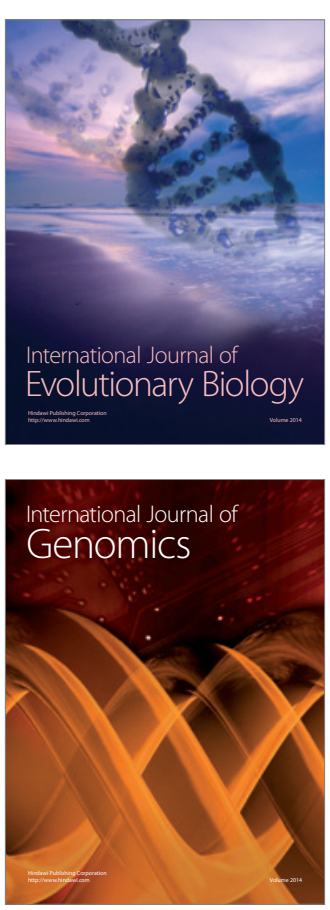
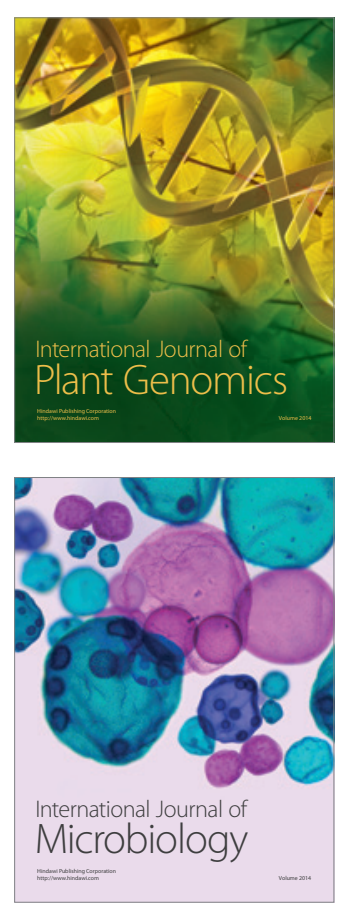

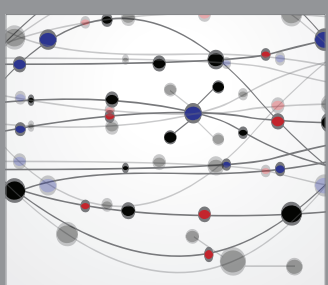

The Scientific World Journal
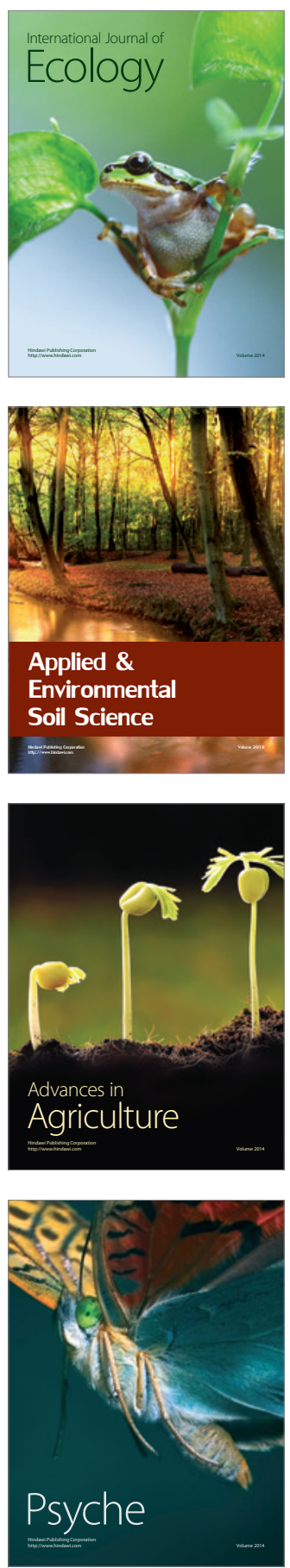